Article

\title{
A Cybercartographic Atlas of the Sky: Cybercartography, Interdisciplinary and Collaborative Work among the Pa Ipai Indigenous Families from Baja California, Mexico
}

\author{
Martín Cuitzeo Domínguez Núñez
}

check for updates

Citation: Domínguez Núñez, M.C. A Cybercartographic Atlas of the Sky: Cybercartography, Interdisciplinary and Collaborative Work among the Pa Ipai Indigenous Families from Baja California, Mexico. ISPRS Int. J. Geo-Inf. 2022, 11, 167. https:// doi.org/10.3390/ijgi11030167

Academic Editors: Fraser Taylor, Romola V. Thumbadoo and Wolfgang Kainz

Received: 22 November 2021

Accepted: 24 January 2022

Published: 28 February 2022

Publisher's Note: MDPI stays neutral with regard to jurisdictional claims in published maps and institutional affiliations.

Copyright: (C) 2022 by the author. Licensee MDPI, Basel, Switzerland. This article is an open access article distributed under the terms and conditions of the Creative Commons Attribution (CC BY) license (https:// creativecommons.org/licenses/by/ $4.0 /$ )
Escuela de Antropología e Historia del Norte de México, Instituto Nacional de Antropología e Historia, Chihuahua 314110, Mexico; martin_dominguez@inah.gob.mx

\begin{abstract}
In this article, I discuss how sky mapping was carried out among the Pa Ipai peoples from Baja California in Mexico. This mapping was elaborated through an interdisciplinary study that combined cybercartography, ethnography, cultural astronomy, semiotics, and collaborative work. The central argument of the article focuses on how the cybercartographic sky atlas of the Pa Ipai people responded to the situation and social problems of these communities. Some of these problems are extreme poverty, violence, and conflicts with the Mexican state and the academic world. In this context, the atlas and the collaborative work became tools that created links with indigenous families, especially with the young people. The mapping process also helped to resolve the tensions mentioned above. The article also addresses how the economic and political situation in Mexico has an effect on the preservation of the atlas. Some of the results of this work are that the Pai Ipai atlas allows, conserves, and renews songs, stories, and experiences around heaven. Another remarkable result is that the teenagers have positively received the atlas and the collaborative experience derived from it.
\end{abstract}

Keywords: cybercartography; sky map; collaborative work; Pa Ipai; indigenous; Baja California; Mexico

\section{Introduction}

When I was in the middle of my degree in archeology, around 2003-2004, a book entitled Relatos Pai pai [1] came to my hands. (I spell here the word Pai Pai as it appears in the original title of the book. However, in this text, I will write the word as Paipai since the indigenous communities asked me to do it in that way). This pocket book told stories and myths of the Pa Ipai people, a native indigenous community from Baja California, Mexico, which, according to the back cover, was one of the last hunter-gatherer societies in Mexico. The book caught my attention because it contained some astronomy stories. I thought that this indigenous knowledge had already disappeared in Mexico.

At that time, the professors emphasized how important it was to study the archeology and anthropology of northern Mexico, so I tried to study this region and later I joined to some archaeological projects. The beginning of the war against drug trafficking in 2007 made it very difficult to continue researching in northern Mexico. My colleagues and I moved away for safety.

In 2016, I returned, starting a field work in Baja California with the Pa Ipai people, and I was interested on conducting doctoral research on Pa Ipai astronomy. The objective was to carry out interdisciplinary research that combined semiotics (Semiotics consists on the study of signs and meanings in culture), anthropology, astronomy, cultural astronomy (Cultural astronomy studies how the sky is part of a cultural construction), and cybercartography. From these lines of research, I sought to create a cybercartographic atlas of the Pa Ipai sky.

Despite the expectations and the initial objectives that I had set out for myself, the beginning of the work was a shock. I faced rejection from the community because there was great anger towards anthropologists. There was also fear of strangers as a product of 
years of violence. Additionally, I assumed that it was no longer true that Pa Ipai people were a hunter-gatherer society.

This article deals with how the initial rejection and the misunderstandings became a source of reflection that led to the development of a collaborative methodological process and in the cybercartographic atlas of the sky Pa Ipai. I also discuss how the contemporary history of Baja California and Mexico had effects on the methodological process.

The main question I am trying to answer is how and why the atlas became a collaborative tool for working with Pa Ipai people. In other words, I want to explain the methodological route followed in its elaboration. As an argument I propose that the atlas built bridges with the Pa Ipai community since its interactive and collaborative characteristics found resonance with the way of life and values of Pa Ipai families, especially among the youngest.

First, I discuss who the Pa Ipai are and where they live. Then, I will raise the background of the research in the region and define cybercartography. The next step is to describe the misunderstandings from which the research started. Then, I explain the celestial atlas and its elaboration. Finally, in the discussion, I interpret and explain the process, as well as the way in which contemporary historical situations shaped it.

\section{The Pa Ipai People and the Research in the Region}

The Pa Ipai indigenous people are located in the Municipality of Ensenada, in Baja California, Mexico. They are one of the five Yuman groups that inhabit the Baja California peninsula. The Pa Ipai live in the towns of Santa Catarina and Héroes de la Independencia, a town to which they had emigrated for economic reasons. They have also migrated to the cities of Ensenada, Mexicali, Tijuana and Tecate.

They were originally hunter-gatherer fishermen, but currently they are engaged in various activities, such as forestry, handicraft and informal trade. Their language is at risk. During my field work, unlike what INALI (National Institute of Indigenous Languages) (2016) and INEGI (National Institute of Geography and Statistics) [2,3] (2010) report, I found that there were less than 12 fluent speakers of Pa Ipai. Despite this panorama, there are attempts to revitalize it both by the families themselves and by the sporadic and intermittent programs of the Mexican state.

\section{Research in the Region}

Gifford and Lowie [4] revealed in the 1920s what the Pa Ipai society was like at the beginning of the 20th century. In this work, the authors revealed the social organization, the belief system and the world of myths of this society.

In the 1930s, Meigs [5] studied the remains of the Santa Catarina Mission as well as the elements that were introduced by the missionaries and the resistance process that culminated in the destruction of the mission. Meigs also constructed a map of the ruins of the mission.

During the 1950s, reports about Santa Catarina were published in Desert magazine. Around this time, Ralph Michelsen worked with Pa Ipai families and made descriptions regarding the collection of the pine nut [6].

In the 1960s, Roger Owen carried out a study about traditional Pa Ipai medicine [7] This work gives in its first chapter an overview of the life, economy and social structure of families at the end of the 1950s. This work allows us to realize how certain economic activities, such as livestock and agriculture, have almost disappeared among this society. Owen shows how the world of families was already immersed in the modernizing dynamics of the region.

Thus, when reading the pages, we realize how the ranch world, automobiles and the Pentecostal and spiritualist religions were already present and shaped their daily life. At the end of this decade, Owen, Walstrom and Michelsen [8] investigated the renewal processes of Pa Ipai songs. In this decade, Judith Joël also carried out her work on phonology and in the transcription of oral stories [9]. 
In the 1970s, Mason [10] revealed how the Pa Ipai region of Santa Catarina began to be colonized by the Spanish from the second half of the 18th century, and how it became a strategic space for passage to the territories from the North. In 1994, Garduño wrote a book about the history and ethnography of the Yuman peoples. It is the most comprehensive book on the subject so far. The book includes elements of the history and anthropology of the Pa Ipai families [11].

On the other hand, Everardo Garduño has shown that the identities of indigenous peoples from Baja California have been revitalized and reinvented in a binational context throughout history. Garduño also revealed the existence of four major historical stages: the arrival of the missionaries, the arrival of Mexican ranchers, the arrival of North Americans, and their existence in the 21st century, in which native peoples have built new flexible ethnicities [12].

In 2009, Lee Panich excavated the ruins of the Santa Catarina mission. These excavations evidenced how the arrival of the Dominicans, rather than representing a total displacement of local cultures, represented a process of continuous negotiation in which the inhabitants of the missions conserved their collection, hunting and fishing patterns [13].

Silvia Yee studied contemporary Pa Ipai identity in her Master's thesis, published in 2010. This work also provided a general ethnography that gives an account of the state of the language, the economy, social organization, festivals, religiosity and life cycles. One of the main findings of this thesis was that there are two determining factors in Pa Ipai identity: blood ties and belonging to the town of Santa Catarina [14]. In that same year, Yee published a work on the morphology of Yuman languages, including that of the Pa Ipai [15] (Yee, 2010b).

In the second decade of the 2000s, studies were carried out on Pa Ipai herbalism and local development [16]. In 2015, Ibáñez published a work on the phonology of the Pa Ipai [17].

In the following year, Sánchez carried out a study of the deixis of the Pa Ipai language [18]. In that same year, Nina Martínez's doctoral thesis on Pa Ipai time was also published, in which she discusses contemporary Pa Ipai calendars and seasonality [19]. In 2016, an outreach book for children entitled Pai Pai Numbers and Skies [20] was published. The text explores the Pai Pai numbering system, the lunar calendar and a short story about the constellations.

In 2018, Gerardo Buenrostro published his Master's thesis concerned with how intangible cultural heritage is built among Pa Ipai families as a negotiation strategy [21]. Additionally, in 2018, Ruelas [22] described the processes of coexistence of Pa Ipai music and northern music.

One year after, in 2019, Margarita Parás, Martín Domínguez and Amílcar Morales wrote a text about the indigenous territories of Baja California from a semiotic perspective [23]. Collaborative works are also scarce; however, we have the case of Buenrostro and the ongoing work of Alejandra Velasco on the development of productive projects with $\mathrm{Pa}$ Ipai artisans (Velasco, personal communication).

This bibliographic review reveals that the themes of the territory, the sky, technology and young people have hardly been addressed. These four themes, however, are important in this investigation. I realized this during the atlas work with the Pa Ipai families, since I learned that the Earth and the sky are different parts of the same territory. I also realized that technology is a tool for collaboration and that young people are key in this process. These circumstances, as I will relate below, were the context for the development of a cybercartography atlas of the Pa Ipai sky through interdisciplinarity and collaborative work.

\section{Indigenous Mapping, Cybercartography and Interdisciplinarity}

\subsection{Indigenous Mapping in the World and in Latin America}

The elaboration of maps, in general, has historically depended on those who possess the resources for their production. Their access was restricted to the population [24], especially to indigenous people. It was not until 1960s when indigenous mapping began in 
Alaska and Canada. Its goal was contrary to that of traditional maps and it was sought that these maps became tools to negotiate the rights of indigenous peoples over their lands. Mapping was incorporated into public policy in 1950 in the North Slope of Barrow's Inupiat region of Alaska in order to resolve land-related conflicts. Another project was also developed in the Inupiat region of Cape Thompson. From here, methodologies were derived, such as the map biography, which sought to trace subsistence patterns of individuals through time. This methodology became an official method for land reclamation [25].

In Oceania, South Asia and Latin America, various indigenous mapping projects have been developed in Indonesia, Papua New Guinea, Thailand, Belize, Nicaragua, and Honduras. In these collaborative mappings with indigenous communities, GIS has been incorporated; however, the issue is controversial because there has been a misuse of the term collaborative mapping. This word has been used indiscriminately in environments as diverse as business management, accounting, and conservation, among others [25]. With regard to this, in the discussion of this article, I am going to explain how I define collaborative research.

In Latin America, indigenous maps have played a key role in the recognition of territory and indigenous identity struggles. In this, both the mapping process and the maps themselves have been fundamental; however, it has been the elaboration of the maps that has politicized identity and territorial rights and has contributed to the transmission of the knowledge from the elders to younger generations [26]. The importance of the mapping process is also highlighted by cybercartography and is one of the main themes of this article.

\subsection{Cybercartography and Cybercartographic Atlases}

Cyber cartography is defined, according to Fraser Taylor, as "the organization, presentation, analysis and communication of spatially referenced information on a wide variety of topics of interest and use to society in an interactive, dynamic, multimedia, multisensory and multidisciplinary format" [27]. In other words, it consists on a set of tools and concepts that combine participatory mapping with geographic information systems and multimedia [28]. The concept of cybercartography has recently been redefined and applied in indigenous and international contexts. Its main product is the cybercartographic atlas.

It is an interactive platform that allows collecting, relating, presenting and preserving information with particular emphasis on maps as a unifying framework. Reflections have begun to revolve around the manufacturing process, rather than the product itself. Finally, emphasis has been placed on how cybercartography summarizes two human characteristics, mapping reality and telling stories [29].

It has also been suggested that cybercartography extends beyond the visuality of traditional cartography and that this methodology proposes the use of all sensory modalities. This allows us to find more efficient, natural modes and to turn on through interactive maps. In the same way, cybercartography not only visualizes, but explores sound and the sense of touch, as it has been proposed by Lean, Lindgaard and Dillon [30].

\subsection{Interdisciplinarity}

In this article, I propose a knowledge framework for the the cybercartographic atlas based, on interdisciplinarity, which arises from the need to integrate knowledge in the face of the hyper-fragmentation of current science. It is located between, through and beyond the particular disciplines and considers a reality composed of multiple levels and dimensions [31].

It is about transferring concepts, methods and principles, as well as extending beyond the vision of a single discipline. A characteristic of interdisciplinarity is called Modality 2, which consists of a type of research where problems and proposals arise through dialogue between different actors and different perspectives. The dialogue between academics and society stands out especially [31]. This question resonates strongly with the collaborative 
research proposal. From my point of view, interdisciplinary and collaborative research can become convergent. For this reason, both approaches are used in this work.

I started from an approach in which I used methods and concepts from cultural astronomy, responsible for studying the relationship between the sky, astronomy and human activity [32], ethnosemiotics, understood as the description of the everyday behavior from of semiotic tools [33], and cybercartography, which has already explained above. This work also brought history into the dialogue, as a discipline that studies the past, and ethnography, understood as an experimental history of a present made up of multiple layers of time [34], an issue that implies creating relationships, facing a diverse and multiple network of structures that overlap and intertwine with each other [35]. Also, etnography is about elaborate, observe, create and interpret an empirical reality [36].

\section{Elaboration Process}

\subsection{Difficulties and Misunderstandings}

Now, I will start exploring the elaboration process of the Pa Ipai cybercartographic atlas. The ethnographic field work was carried out between 2016 and 2017 with returns in 2018 and 2019. In the first months, I found myself faced with difficulties, such as rejection and silence in the face of my presence and the investigation I was carrying out. I was constantly questioned regarding what I was doing there and what the benefits that the people were going to derive from my presence and research. Keneth, one of the Pa Ipai teenagers with whom I worked, told me that:

"People are suspicious because other anthropologists have come and taken photos.

With them they have made books about the Pa Ipai and they have become rich selling those books in Spain."

As this shows, there is distrust towards the researchers. This rejection is the product of the annoyance of the Pa Ipai people with the institutions of the state, its programs and anthropologists. Anthropologists and institutions are perceived to extract knowledge without giving anything back to the community. Authors, such as Roger Owen [7] and Everardo Garduño [11], have spoken of this rejection of anthropologists and institutions.

The works carried out in the 1950s and 1960s were characterized by extractivism, non-reciprocity, and payment in dollars for the interviews. Even today, there are colleagues on both sides of the border who work along this vein. It should be noted that crafts and language, among other elements, have become a commodity. At the same time, the relationship between anthropologists and social actors has been reified. All of this had an effect on my field work and became a difficulty to overcome since I was associated with this modality of working.

It is felt that researchers and institutions "do not pay what they should" for the information that has been provided to them. This generates very great annoyances that are translated in phrases such as:

"I no longer work with anthropologists because I don't take anything with me."

This situation of shock and rejection led me to think that I was facing what in ethnography is called misunderstandings or equivocations. An equivocation is a clash, a breaking point between the anthropologist's vision and that of the peoples with whom he works [37] (Viveiros, 2004: 4-5). An equivocation is not just a "a way of behaving or speaking that is not clear or definite and is intended to avoid or hide the truth" [37], but a failure to understand that understandings are necessarily not the same, and that they are not related to imaginary ways of "seeing the world", but to the real worlds that are being seen [38].

Equivocations are also very close to misunderstandings. Anthropologist Michael Taussig points out that" one way of highlighting this is to lay bare what goes on in anthropological fieldwork as a prolonged encounter with others fraught with misunderstandings that actually open up the world more than do understandings" [39]. Thus, for Taussig, misunderstandings in the field reveal more than coincidences. 


\subsection{Different Visions of Heaven}

The mistakes and misunderstandings led me to a systematic methodological and ethnographic reflection with respect to the kind of equivocations I encountered in the field. Viveiros de Castro calls this method "controlled equivocation". This method is based on the review and analysis of the turning points and misunderstandings between the anthropologist and the peoples with whom he works [37]. It is precisely these errors and misunderstandings that lead to the building of bridges and to new understandings of social worlds. In this specific case, this reflection ended up shaping the process of elaboration of the Pa Ipai sky atlas.

One of the misunderstandings I found consisted in my idea of heaven and that of the families. It was a contrast of visions about heaven. While for me the sky was an object of fascination and study, the families saw the sky as something far away, as something that had no direct relationship with them, as something for which there was no time and that it belonged to the past.

However, despite this, the sky appeared at certain specific times, as I will explain, as something that was there latent. This contradiction meant that, throughout the fieldwork, I became more receptive to the interests and needs of families and their relationship with heaven.

Another mistake had to do with my vision, which was centered on my own research and interests about the sky. This vision was alien to local social logic. Rather, these logics focus on family structure and obtaining a livelihood. This structure also seeks for each member to fulfill their social function and to do things "as they should be". Thus, the presence of the anthropologist generates certain ruptures because he does not contribute to the daily sustenance, nor to the family structure. In the section referring to the process of elaboration of the atlas, I explain how these misunderstandings were resolved, but before that, I describe the Pa Ipai sky atlas.

\section{Description of the Atlas}

The cybercartographic atlas of the Pa Ipai sky consisted of an interactive map of the sky and the territory that allowed to present, relate and preserve knowledge, representations and practices about heaven and Earth, through the use of different senses. It can be found in the following link: https://nunaliitworkshop.centrogeo.org.mx/paipai/index.html? Module=module.skystorymap (accessed on 30 November 2019).

The image on which the atlas is based consists of three levels. Figure 1. It has already published in another text about the study of the territories of the indigenous peoples in Baja California [23]. The first level is the land, in which we find the two coasts of Baja California, the mountainous area, and the towns of Héroes de la Independencia and Santa Catarina; in this dimension, we can also find the sun. In the second level, the moon and other elements of the sky are located. Finally, on the third level are the constellations.

The drawing emerged from the dialogue with the families. It was prepared by the author of this article and summarizes the astronomical knowledge that I found in the field. The drawing was inspired by the style of astronomical drawings that children and families made during the Nunaliit workshop in February 2018.

Each element of the atlas, when touched with the cursor, activates a series of hyperlinks that connect with other documents. These documents consist of audios, songs in Pa Ipai, drawings and photographs about celestial objects. Both the drawings and the photographs were made by the families. The audios are excerpts from the interviews and conversations I had at the end of the fieldwork with the families.

In Figure 2, the scheme summarizes and explains the previous image. First, this diagram allows the audience to visualize the names of each of the elements of the Pa Ipai sky, as well as the three levels in which the image is divided. In the following section, each of the levels of the map is explained, together with the elements that constitute it. 


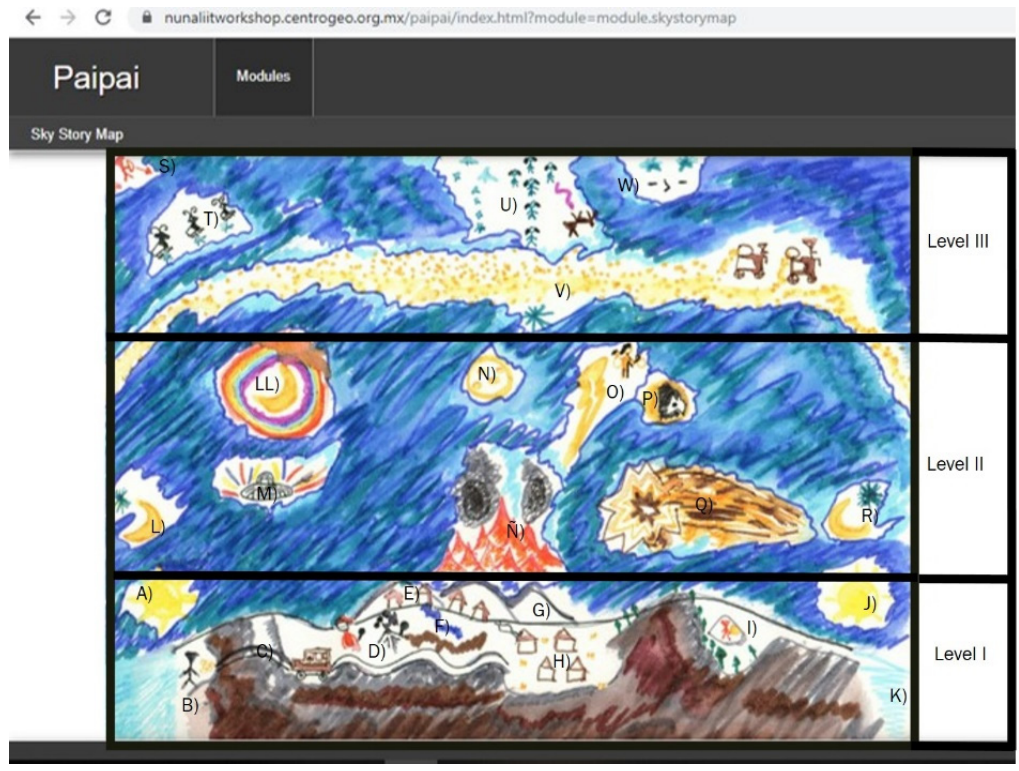

Figure 1. Pa Ipai sky cybercartographic atlas.

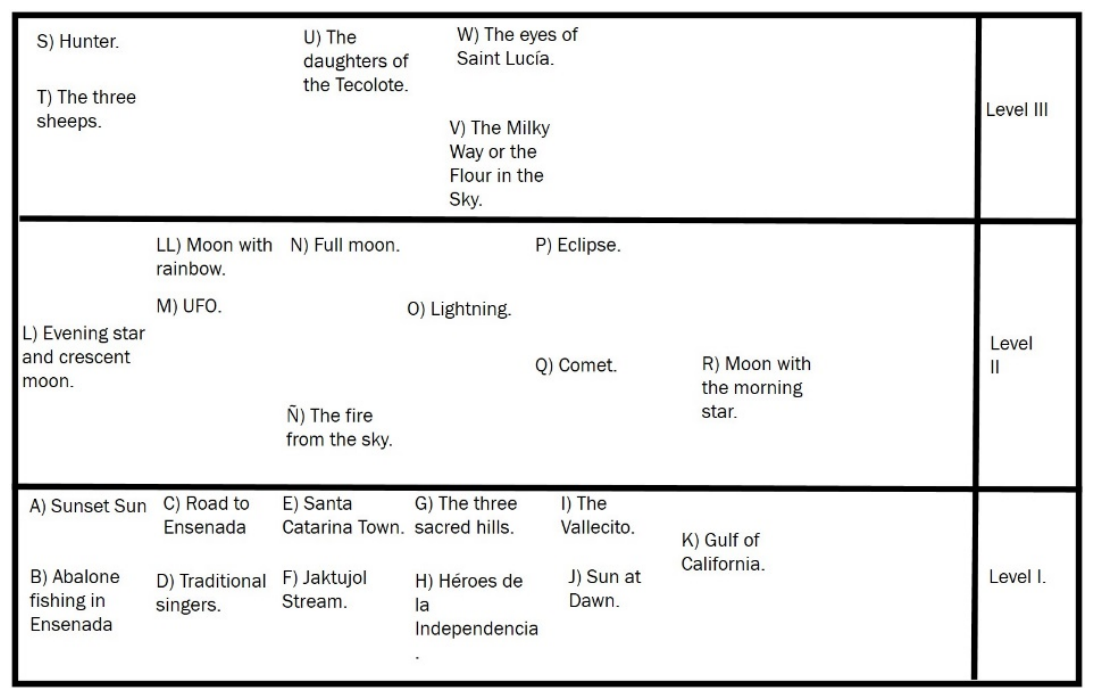

Figure 2. Pa Ipai sky cybercartographic atlas.

\subsection{First Level: The Territory}

The cybercartographic atlas, in the section corresponding to the territory, graphically summarizes the characteristics of the Pa Ipai territory and their localities. Both Santa Catarina and Heroes of Independence are represented in the atlas. It is precisely because this first section of the atlas summarizes and illustrates the Pa Ipai territory that I proceed to explain and describe it in this section. The aim for the reader to have a clearer image of the territoriality of families, both in the past and in the present.

In this first section, which is in the lower part, Baja California can be seen as well as the sites in the territory that were and still are important for the indigenous families today. On the left side with an A, we have the sunset, then with the B the coast of Ensenada and a drawing of the abalone and shell of Pa Ipai fishers. Letter $C$ is the road that leads to Ensenada. D shows two Pa Ipai traditional singers, E represents the Pa Ipai town of Santa Catarina, $\mathrm{F}$ is the Jaktujol Stream that crosses Santa Catarina and G represents the three sacred hills of the Pa Ipai. H is the town of Héroes de la Independencia. The letter I represents the rock art site known as "El Vallecito", letter J represents the sun dawn and the letter K represents the Gulf of California and the San Felipe port. 


\subsection{Second and Third Level: Heaven}

The second and third levels summarize the knowledge of heaven. The letter L represents the evening star and the crescent moon. LL is the moon with a rainbow around it. It represents a phenomenon that is seen as being associated with war. $M$ is an image of an UFO, $\mathrm{N}$ is the full moon, and the $\mathrm{N}$ represents the story of the day when there was a fire in the sky. O signifies a lightning bolt and a woman with a baby on her back. By clicking on this image, the narration of the myth unfolds, which tells why the lightning bolts sound. $\mathrm{P}$ is the representation of an eclipse, characterized by a moon with a coyote's face inside. This image is associated with a drawing with a text about eclipses made by Delfina Albáñez, and there are also narrations about the eclipses that accompany this image. $\mathrm{Q}$ is the image of a comet and, to the right of this section, is $\mathrm{R}$ that represents crescent moon with the morning star above it.

In the third section, which is located above, we find the asterisms, the Milky Way and the constellations. In the upper left part with the letter $S$, a hunter in red can be seen, under him it is the letter $\mathrm{T}$, where there are three mountain sheep, both of which are part of a myth about an ancient hunting. In the center marked with the letter $U$, the daughters of the Tecolote or owl can be seen. They represent another myth about seven girls that found revenge against the Coyote. Marked with the letter W is another asterism, Saint Lucia's eyes. Finally, there is the letter V, which represents the Milky Way or the story of how flour reached the sky.

These celestial elements make up the Pa Ipai astronomical landscape. However, in this work, I am not going to discuss all of them because of restrictions of space. The items that I chose to explore are those about which I obtained more information in the field, but also those that are more accessible. On the other hand, I chose those elements and knowledge that best illustrate the relationship between heaven and Earth.

\subsection{Multimodality}

The atlas developed here was a multimodal text that combined several semiotic systems to account for the various meanings of the sky. These different semiotic systems were the linguistic, the visual, the spatial and the verbal. These characteristics are linked to what was mentioned by Lean, Lindgaard and Dillon regarding atlases as multimodal tools [30].

At the same time, on this platform, what is called syncretism in semiotics occurred, since when the names of the stars, songs, narratives, drawings and photographs were recorded on this map, a mixture occurred between the different semiotic systems used, as Rosales explains [40].

\section{Atlas Production Process}

From the dialogue with the families throughout the months of fieldwork emerged a drawing, made by me, and that summarized the astronomical knowledge that I found in the field. The drawing was inspired by the style of astronomical drawings that children and families made during the Nunaliit workshop in February 2018.

The atlas was co-created during several stages. The first was during collaborative work in the field and started from an attempt to resolve the misunderstandings and equivocations. The second stage consisted of the Nunaliit workshop that was held in the city of Ensenada. The third stage was during a one-month work stay at Carleton University of Ottawa in Canada, in May 2018. The last stage took place when I returned again to Heroes of Independence and I presented the map to the teenagers and adults.

\subsection{Collaborative Work in the Field and Methodological Resolution of Mistakes}

The difficulties and mistakes described above implied the adaptation of the methodological tools, as well as a change in the methodological strategy during the field work. Thus, instead of conducting interviews and proposing the making of drawings as was proposed in the beginning, I began to extensively interact with the families in their daily 
activities, and I tried to listen, observe and see how it was possible to work collaboratively with the families.

As time went by, the families mentioned some elements that were important to them, such as songs of their grandparents that had been recorded by the National Indigenous Institute in the 1970s and 1980s. These songs had never reached the community. I located these songs in the library of the Commission for the Develop of the Indigenous People in Ensenada; I asked permission to obtain their recording and began with their digitization. Juana Reza, granddaughter of one of the main singers, helped me and edited part of the songs.

Another request was to hold a workshop for the formulation of cultural projects and to request support. Then, I organized a workshop for that purpose. Finally, the young Pa Ipai and their mothers asked me for help with their homework, as well as with English classes. All of these activities contributed to break the initial rejection and building bridges.

Finally, the families posed two questions to me: on the one hand, they showed interest in being able to have a map of the Pa Ipai territories, and on the other hand, the young people expressed their interest in technologies. The cybercartographic atlas that was subsequently produced resonated with these needs and interests.

\subsection{Workshop in the City of Ensenada}

The workshop took place in the city of Ensenada in February 2018. Although the three Pa Ipai families with whom I worked were invited, only the Albáñez family attended as the other families had activities that prevented them from attending. The workshop was also attended by the Kumiai families from Juntas de Nejí and San José de la Zorra invited by other researchers and who were interested in collaborative mapping.

The objective of the workshop was to introduce the families to the Nunaliit software tool, so that from it they could make maps and atlases of their interest. As can be seen in Figure 3, the main interest of the attendees revolved around how to develop digital maps of their territories, although a part of the sky atlas was also made. This workshop was organized by the Geomatics and Cartographic Research Centre (GCRC) (GCRC, 2021) from Carleton University in Ottawa, Centro Geo (Centro de Investigación en Ciencias de Información Geoespacial, Conacyt, Mexico. https://www.centrogeo.org.mx/) (accesed 28 December 2021), Ciesas (Centro de Investigaciones y Estudios Superiores en Antropología Social, Conacyt, Mexico. https://ciesas.edu.mx/), (accesed 28 December 2021), and Terra Peninsular (TerraPeninsular, NGO from Baja California, México. https: / / terrapeninsular.org/en/), (accesed 28 December 2021).

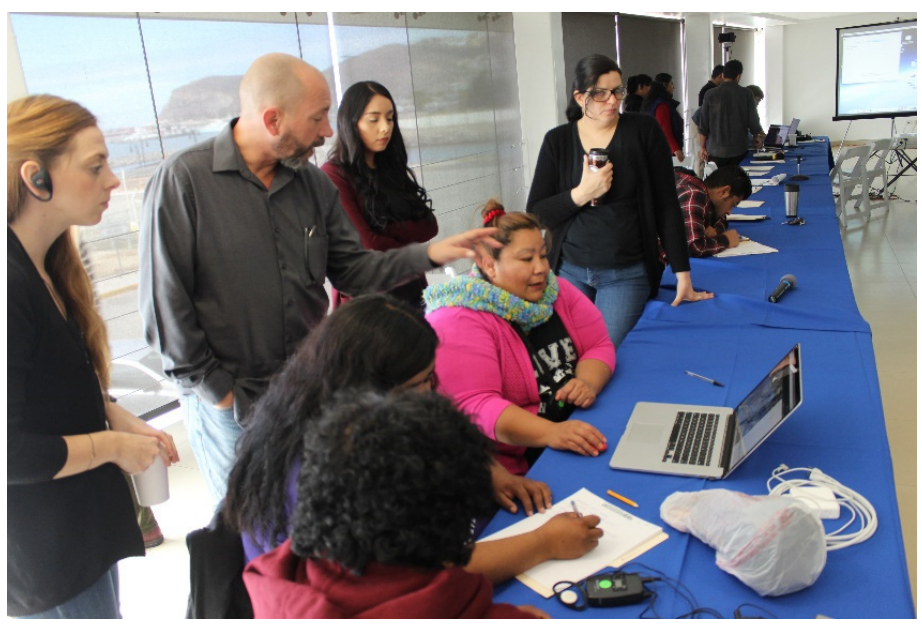

Figure 3. Nunaliit workshop in the city of Ensenada. Pa Ipai families during learning how to use the Nunaliit software. Credits: Martín Cuitzeo Domínguez Núñez. 
During the field work, the families expressed this interest; however, I could not fulfill them because neither did I have the technological tools nor the knowledge to elaborate this kind of digital maps. The violence in the region was another obstacle that did not allow traveling through the territory of the Pa Ipai and documenting the geographical elements.

Members of the Nunaliit team from Carleton University in Ottawa participated in the workshop. They worked and conducted research with the Inuit in Alaska and made an atlas about Inuit geography, such as the Siku Atlas [41]. This generated special interest among several of the young Pa Ipai women who asked about the work conducted with the Inuit and by the Inuit atlas.

I was in charge of conducting the workshop during the two days it was held. The workshop had several activities. The first was that the participants collectively raised the problems they had in common, but they also raised them in particular. Among these problems appeared the following: garbage, violence, invasion of land, drug addiction, unemployment, lack of opportunities, lack of services (hospitals, internet signal and schools), loss of language and customs, robberies, looting and massacres (Figure 4).

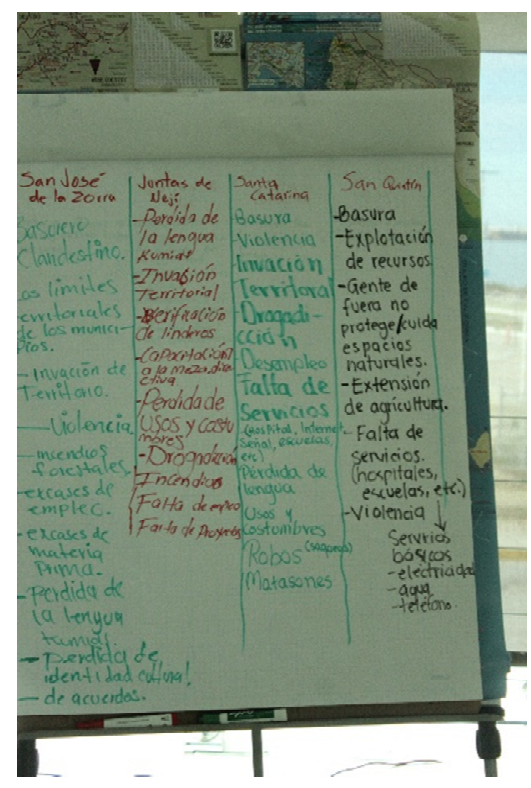

Figure 4. Nunaliit workshop. Enumeration of the problems of the region. Credits: Martín Cuitzeo Domínguez Núñez.

Then, throughout the workshop, the members of the Nunaliit workshop presented the results of the atlases made with the Inuit. For my part, I had to propose and direct some dynamics. One of these dynamics was the rotation in circles. This activity involved the participants forming in two circles. The circles were turning, and the participants introduced themselves to each other. This created trust between the different participants.

Regarding the software and the platform, young Pa Ipai adults, especially the women, showed interest in learning to use the Nunaliit platform. The work that they produced in the first instance was a map of their territory. For this, they located the important geographical points and their names in Pa Ipai. Children and teenagers also participated, although it was more difficult for them than for adults to locate the points on the digital map.

An Inuit video game was presented at the workshop. In it, the challenges and activities were related to Inuit myths and stories. The children were very interested in this video game. It was essentially about an Inuit girl and a white fox that was an Inuit spirit. Together they must overcome obstacles in the middle of the snow. In this context, the teenagers asked how they could learn to play video games.

At the end of the workshop, there were several results. First, we obtained the Pa Ipai geographic maps, where hills, streams, stories and songs were located in Pa Ipai. Another 
result was the execution of the drawings on the moon, the stars and the constellations (Figure 5). Of special worth was the construction of a list of the names of stars in Pa Ipai.

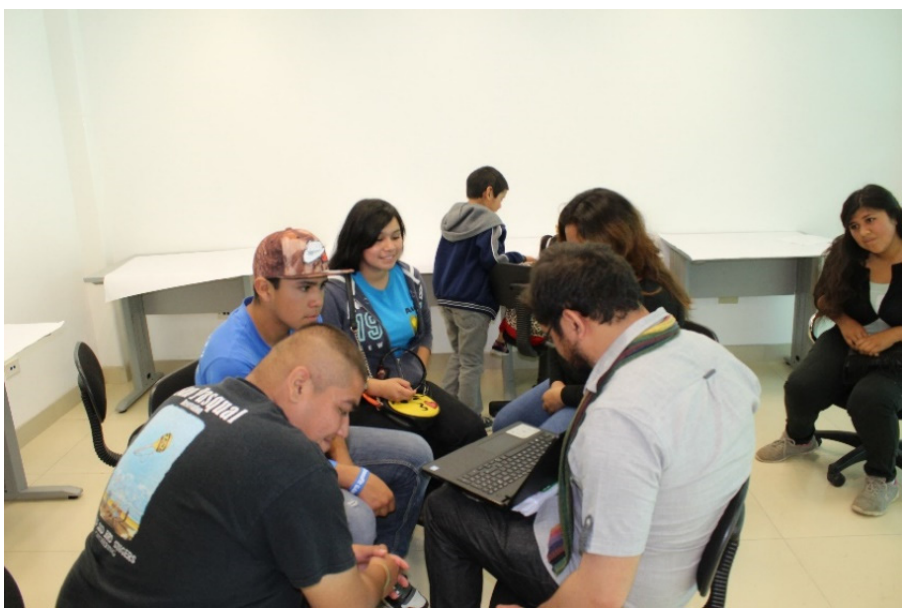

Figure 5. Nunaliit workshop. Drawing session with adolescents and children. Credits: Gerardo Buenrostro.

\subsection{Short-Term Research at the Geomatics Laboratory at Carleton University}

Another stage in the elaboration of the atlas consisted of a one-month stay at Carleton University in the Geomatics and Cartography Research Center. During this stage, the programing part and the digital part of the atlas were made. During the stay, I learned basic elements that allowed me to use the Nunaliit platform and to create the interactive maps.

Nunaliit is composed of modules and schematics and is document oriented. In the Nunaliit platform [42], the diagrams are guides and maps that show the way in which the data were collected. Using the platform led me to wonder about the information I had collected and the reason why I had collected it. The more specific question was how I could project the field experience on a map of the sky. The final structure of the atlas was an answer to these questions.

\subsection{Atlas Reception}

Finally, the last stage was the return to the field and showing the atlas to the families. The interactive features of the atlas were especially interesting to the teenagers who, I must point out, were very interested in the atlas. This is the result of the relationship they have with new technologies, but it is also a consequence of the new construction of their identity as Pa Ipai and young people.

One of the teenagers that was most interested in the atlas was Tatiana, aged 15. After I showed and shared with her the atlas in her aunt's internet cafe, she spent some time interacting with the platform. She also asked me about the use of the platform and its contents. She told me that she did not know some of the stories in the atlas. The platform also had an impact on young adults. Delfina Albáñez encountered the atlas during a visit to Mexico City. She pointed out that she liked the platform and that there were story elements of which she was unaware.

\section{Discussion and Interpretation of the Process of Elaboration of the Atlas}

\subsection{The Atlas as a Collaborative Process}

Undoubtedly, an important question to answer in this article is why the atlas became a methodological input for working with Pa Ipai people, especially the youngest among them. The answer, in my view, is related with the entire collaborative process, not only with the atlas itself. In this sense, I must mention again what Taylor pointed out about how recent research in cybercartography focuses on the process rather than on the final product, which is the atlas [29]. 
The process was collaborative since, from the beginning, the mistakes and the initial rejection led me to reflect from where, for whom, for what and how I was building knowledge about the sky. Leyva precisely points out that these questions are the axis that leads us to a reflective position around non-extractive knowledge production practices [43].

I believe that the process was collaborative because it was conceived as a co-construction of knowledge. In the end, I realize that my initial mistakes contributed to the generation of a dialogue between the social actors and me. Keneth, one of the Pa Ipai adolescents with whom I worked, told me at the end of the investigation that the work was "ours" and that "we were writing it together".

This point allows me to return now to the definition of collaborative research. Andrés Aubry noted that it consists of breaking with the "extractive practice" of anthropology, since only taking "data from a community without returning anything is an intellectual dispossession" [44].

In this regard, both the return of the songs, the workshop on cultural projects and the cybercartographic atlas were a way of returning what learned with the social actors during the field work. In this process, I must point out, there was a transformation both in the social actors with whom I collaborated and in myself and in the methodological procedures. Aubry pointed out in this regard that " ... the encounter of the researcher and the social actor is always transforming, of both and of the observed and analyzed reality" [44].

I return to the question indicated at the beginning of this section, that is, why the atlas allowed us to build bridges especially with the youngest generation. I think this happened because the atlas is an interactive digital format, and being in this medium, it became an attractive language that young people could understand.

Since 2012, when mobile phones arrived in the region, technologies are part of the daily life of the young Pa Ipai. Recently, youths and young adults have started to connect to the internet and become active participants in social media. From this moment on, social media, the internet and the cell phone are tools that allow young people to build and negotiate the representation they have of themselves and their culture in front of others, especially of the identities and daily life of teens and young adults. This happened not only among the Pa Ipai, but also throughout Northern Mexico and in the rest of the country.

Finally, it should be noted that the workshop that took place in the city of Ensenada was understood and interpreted by the families as a return, as an action of reciprocity. Thus, it was within this framework that appeared the drawings of the stars and their names in $\mathrm{Pa}$ Ipai and other materials that made up the atlas. It was also in the workshop where the adolescents made their interest in information technology explicit and where their interest in making interactive maps was confirmed.

\subsection{Historical Situations and the Elaboration Process}

In order to understand and interpret the phases and sequences of the process of making the atlas, it is important to understand the effect of the historical and social situation in Mexico and Baja California today. To this end, I will briefly recapitulate the sequence here so that it can be interpreted. There were four stages:

1. Collaborative work in the field and solution of mistakes and misunderstandings.

2. Carrying out the workshop in the city of Ensenada.

3. Stay in the Geomatics laboratory at Carleton University.

4. Reception of the atlas.

I argue that historical situations in the context of Mexico and Baja California shaped these stages. The first stage, full of equivocations and misunderstandings, is related to the rejection of anthropologists for their extractivism, but it is also linked with the violence that since 1998 has plagued the region. The violence has been provoked by organized crime and drug trafficking [45] and by the militarization of the region, with the presence of a military camp in Santa Catarina. Violence causes strangers to be rejected because they are afraid of people who are not from the community. At the same time, deterritorialization and land theft as well as anger with the different institutions of the Mexican state has contributed to this distancing. 
In contrast, the collaborative work that responded to these circumstances is also the effect of changes and transformations in the way of conducting anthropology in Mexico since the indigenous outbreak in Chiapas during the year 1994. The irruption of the indigenous world as a political actor and the claims around indigenous autonomies has changed the relationship of the researchers with the peoples and communities. This has led Mexican anthropologists to develop cooperative work methodologies.

The second and third stages are connected with the cooperation links between academic institutions in Mexico and Canada. Neither the workshop nor the atlas would have been possible without international cooperation, and without funding from the Nunaaliit team.

The reception of the atlas especially on the part of the youth and young adults $\mathrm{Pa}$ Ipai responds to a demographic change. Young people are the population base of their communities. They play a key role in the revitalization and redefinition of the Pa Ipai culture and its relationship with the external world.

\section{Conclusions}

In this article, I tried to show how and why the Pa Ipai cybercartographic sky atlas became a collaborative tool that allowed to build bridges with the Pa Ipai people, especially with the youngest generation. The methodological route followed in its elaboration and the social and historical reasons for which this route was followed were also discussed.

Although, at first, I argued that the collaborative nature of the atlas was due to its interactive and technological characteristics, as the article developed, it could be observed that it was the entire process of elaboration of the atlas that allowed the construction of collaborative links with the community.

This was the case since, from the beginning of the fieldwork, mistakes and misunderstandings led to a reflection and methodological turn that implied that some of the subsequent steps were built collaboratively. However, in addition, each stage adapted to the interests and social needs of the families while building links and restoring elements to the social actors.

The steps followed in the process took their final form, not only derived from the decisions and negotiations between the social actors and the researcher, but from the specific situations of the Mexican and Baja California historical context, because these situations configured the mistakes, the reflections and methodological modifications and, above all, the responses of the young Pa Ipai to the atlas.

The previous results contribute to the existing research in two areas. On the one hand, they contribute to multidisciplinary research among the Pa Ipai people and in general with the Yuman indigenous peoples from Baja California. On the other hand, it contributes to the reflection on the processes of elaboration of cybercartographic atlases. Regarding the study among the families, the results introduce the questioning of the extractive academic practices in the region, at the same time that they emphasize several areas, such as the sky, technology, collaborative work and the role of young Pa Ipai in the construction, renewal and resignification of their own culture.

In the field of methodological reflection on cybercartographic atlases, the aim was to contribute to the think about the role played by mistakes and misunderstandings in the process of developing the atlases. I also invite the reader to reflect on how the historical situations of the regions and countries where the atlases are elaborated influence and configure the stages of the process. I hope all these ideas are useful.

Funding: This research was founded with a doctoral scholarship from CONACYT (Consejo Nacional de Ciencia y Tecnología) in Mexico, from September 2015 to August 2019. The short-term research at the GCRC (Geomatics and Cartographic Research Centre) from the University of Carleton was funded with a NAPECA (North American Partnership for Environmental Community Participation) grant.

Institutional Review Board Statement: Not applicable.

Informed Consent Statement: Informed consent was obtained from all subjects involved in the study. 
Data Availability Statement: Not applicable.

Acknowledgments: I thank for all their support to the GCRC (Geomatics and Cartographic Research Centre) from the University of Carleton in Ottawa and especially to Fraser Taylor and Romola Thumbadoo for their help both during my short-term research at Carleton University and for the publication of this research article.

Conflicts of Interest: The author declares no conflict of interest.

\section{References}

1. Conaculta. Relatos Pai Pai. Kuriut'Trab Pai Pai Lenguas de México 1; Consejo Nacional Para la Cultura y Las Artes, Dirección Nacional de Culturas Populares e Indígenas: Mexico City, Mexico, 2002.

2. INALI. Proyecto de Indicadores Sociolingüí Sticos de Las Lenguas Indígenas Nacionales. Available online: http:/ / site.inali.gob. $\mathrm{mx} /$ Micrositios/estadistica_basica/index_informacion_general.html (accessed on 11 April 2016).

3. INEGI. Lenguas Indígenas en México y Hablantes (de 5 Años y Más). Available online: http:/ / cuentame.inegi.org.mx/hipertexto/ todas_lenguas.html (accessed on 22 March 2015).

4. Gifford, E.W.; Lowie, R.H. Notes on the Akwala Indians of Lower California; University of California Press: Berkeley, CA, USA, 1928.

5. Meigs, P., III. La Frontera Misional Dominica en Baja California; Instituto de Investigaciones Históricas, Universidad Autónoma de Baja California: Mexicali, Mexico, 2005.

6. Michelsen, R.; Michelsen, M.K. A Piñón Harvest by Pa Ipai Indians. Pac. Coast Archaeol. Soc. Q. 1979, 15, $27-31$.

7. Owen, C.R. The Indians of Santa Catarina, Baja California Norte, Mexico: Concepts of Disease and Curing. Ph.D. Thesis, Departament of Anthropology, University of California, Los Angeles, CA, USA, 1962. Unpublished.

8. Owen, R.C.; Walstrom, N.E.; Michelsen, R.C. Musical Culture and Ethnic Solidarity: A Baja California Case Study. J. Am. Folk. 1969, 82, 99-111. [CrossRef]

9. Joël, J. Pa Ipai Phonology and Morphology. Ph.D. Thesis, Department of Anthropology, University of California, Los Angeles, CA, USA, 1966. Unpublished.

10. Mason, W. A strategic mision: Santa Catarina. J. Calif. Anthropol. 1978, 5, 277-287.

11. Garduño, E. En Donde se Mete el Sol. Historia y Situación Actual de los Indígenas Montañeses de Baja California; Consejo Nacional para la Cultura y las Artes: Ciudad de México, Mexico, 1994.

12. Garduño, E. Cuatro ciclos de resistencia indígena en la frontera México-Estados Unidos. Rev. Eur. Estud. Latinoam. y del Caribe 2004, 77, 41-60. [CrossRef]

13. Panich, L. Persistence of Native Identity at Mission Santa Catalina, Baja California, 1797-1840. Ph.D. Thesis, University of California, Berkeley, CA, USA, 2009. Unpublished.

14. Yee, S. Nechi Yakiu Njan Nimatch “Nosotros Somos los de Aquí” Hacia la Identidad Étnica Entre los Pai Pai de Santa Catarina, Baja California. Master's Thesis, Escuela Nacional de Antropología e Historia, Ciudad de México, Mexico, 2010. Unpublished.

15. Yee, S. Tipología del Cambio de Referencia en las Lenguas Hokanas; Instituto Nacional de Antropología e Historia: Ciudad de México, Mexico, 2010.

16. Cortés, E. Conocimiento Tradicional Herbolario Pa Ipai y Perspectiva de Desarrollo Local en Santa Catarina, B.C. Ph.D. Thesis, Universidad Autónoma de Baja California, Mexicali, Mexico, 2013. Unpublished.

17. Ibáñez, M. Descripción Fonológica de la Lengua Pa Ipá: Y de la Comunidad Indígena de Santa Catarina. Bachelor's Dissertation, Escuela Nacional de Antropología e Historia, Ciudad de México, Mexico, 2015. Unpublished.

18. Sánchez, M. Deixis Espacial y Demostrativos en Lengua Paipai. Master's Thesis, Universidad de Sonora, Hermosillo, Mexico, 2016. Unpublished.

19. Martínez, N. Tiempos Pai Pai. Aproximación Etnográfica al Estudio del Tiempo en la Comunidad Indígena de Santa Catarina en el Noroeste de México. Ph.D. Thesis, Universidad Autónoma de Coahuila, Satillo, Mexico, 2016. Unpublished.

20. González, A.; Takeuchi, N.; Sánchez, M.; Martínez, N. Números y Cielo Pa Ipai Chribchu Eemya Paipái; Centro de Nanociencias y Nanotecnología, Universidad Nacional Autónoma de México: Ensenada, Mexico, 2016.

21. Buenrostro, G. De la Imposición a la Negociación. Patrimonio Cultural Inmaterial Entre los Indígenas Pa Ipai de Baja California. Un Estudio de Caso. Master's Thesis, El Colegio de la Frontera Norte, Tijuana, Mexico, 2018. Unpublished.

22. Ruelas, A. Los Indios Yumanos Vaqueros y el Paisaje: Su Cultura Musical. Available online: https://www.academia.edu/103464 30/Los_indios_yumanos_vaqueros_y_el_paisanaje_su_cultura_musical (accessed on 10 November 2019).

23. Parás, M.; Domínguez, M.C.; Morales, A. The territories of indigenous people of Baja California, Mexico: Semiotic dimensions in the study of landscapes. In Further Developments in the Theory and Practice of Cybercartography-International Dimensions and Language Mapping; Modern Cartography Series; Taylor, F., Anonby, E., Murasugi, K., Eds.; Elsevier: Amsterdam, The Netherlands, 2019; Volume 9, pp. 331-348.

24. Sánchez, R.; Pérez, A. Mapeo 2.0. Ampliando los límites de la cartografía crítica. Ecol. Política 2014, 48, $24-27$.

25. Chapin, M.; Lamb, Z.; Threlkeld, B. Mapeo de tierras indígenas. Annu. Rev. Anthropol. 2005, 34, 1-23.

26. Offen, K. O mapeas o te mapean: Mapeo indígena y negro en América Latina. Tabula Rasa 2009, 10, 163-189. [CrossRef]

27. Taylor, F. The concept of cybercartography. In Maps and the Internet; Peterson, M.P., Ed.; Elsevier: Amsterdam, The Netherlands, 2003; pp. 405-420. 
28. Taylor, F. Some recent developments in the theory and practice of cybercartography. In Developments in the Theory and Practice of Cybercartography. Applications and Indigenous Mapping, 2nd ed.; Taylor, F., Lauriault, T., Eds.; Elsevier: Amsterdam, The Netherlands, 2014; Volume 5, pp. 1-15.

29. Taylor, F. Cybercartography revisited. In Further Developments in the Theory and Practice of Cybercartography; Taylor, F., Anoby, E., Murasugi, K., Eds.; Elsevier: Amsterdam, The Netherlands, 2019; Volume 7, pp. 3-23.

30. Trbovicha, R.L.; Lindgaard, G.; Dillonc, R. Cybercartography: A multimodal approach. In Further Developments in the Theory and Practice of Cybercartography. International Dimensions and Language Mapping; Fraser, T., Anoby, E., Murasugi, K., Eds.; Elsevier: Amsterdam, The Netherlands, 2019; Volume 7, pp. 35-54.

31. Parás, M. Aportes al Conocimiento Científico en Geomática: Un Enfoque de Conocimiento Transdiciplinario. Ph.D. Thesis, Ciudad de México, Centro Geo, Degree Granting University, Mexico City, Mexico, 2008. Unpublished.

32. Iwanisewski, S. Archeoastronomy and cultural astronomy: Methodological issues. In Convegnio Internazionale sul Tema: Archeologia e Astronomia: Esperienze e Prospettive Futura; Accademia Nazionale de Lincei: Rome, Italy, 1995; pp. 17-26.

33. Marsciani, F. Les Arcanes du Quotidien. Essais de Ethnosémiotique; Press Universitaire de France, Pulim: Limoges, France, 2017.

34. Domínguez Núñez, M.C. La Harina en el Cielo Representaciones, Prácticas y Saberes Astronómicos de las Familias Pa ipai y Koal del Municipio de Ensenada, Baja California. Ph.D. Thesis, Centro de Investigaciones y Estudios Superiores en Antropología Social, Ciudad de México, Mexico, 2019. Unpublished.

35. Geertz, C. La interpretación de las culturas; Gedisa: Barcelona, Spain, 1973.

36. Herrera, E. De Cochoapa a Villa de Arista. Mano de obra para la agroindustria. Racialización de la Vulnerabilidad del Jornalero Agrícola. Ph.D. Thesis, Centro de Investigaciones y Estudios Superiores en Antropología Social, Ciudad de México, Mexico, 2018. Unpublished.

37. Viveiros, E. Perspectival Anthropology and the Method of Controlled Equivocation. Tipití J. Soc. Anthropol. Lowl. S. Am. 2004, 2 3-22.

38. Oxford Learners Dictionary. Available online: https://www.oxfordlearnersdictionaries.com/us/definition/english/equivocation?q= Equivocation (accessed on 22 November 2021).

39. Taussig, M. Walter Benjamin's Grave; The University of Chicago Press: Chicago, IL, USA, 2006.

40. Rosales, H. El iconografema. deSignis 2012, 20, 165-173.

41. Inuit Siku (Sea Ice) Atlas. Available online: https://sikuatlas.ca/index.html (accessed on 10 December 2021).

42. Geomatics and Cartographic Research Centre Nunaliit Atlas Framework. Available online: http://nunaliit.org/ (accessed on 13 August 2021)

43. Leyva, X. Una mirada al tomo I. In Prácticas Otras de Conocimiento (s). Entre Crisis, Entre Guerras. Tomo I; Leyva, X., Alonso, J., Hernández, R.A., Escobar, A., Kohler, A., Cumes, A., Sandoval, R., Speed, S., Blaser, M., Krotz, E., et al., Eds.; Clacso: Buenos Aires, Argentina, 2018; pp. 36-103.

44. Benavides, G. Los Braceros de La Malinche en la Asamblea Nacional de Braceros. De Cuando el Cuatlapanga se Fue de Bracero y los Pleitos por la Malintzin. Ph.D. Thesis, Centro de Investigaciones y Estudios Superiores en Antropología Social, Ciudad de México, Mexico, 2008. Unpublished.

45. Cano, A. La Masacre y la Princesa. Available online: https://www.jornada.com.mx/1998/09/27/mas-masacre.html (accessed on 22 November 2021). 